\title{
Contribution of roots and shoots of Brachiaria species to soybean performance in succession
}

\author{
Alvadi Antonio Balbinot Junior(1), Julio Cezar Franchini Dos Santos ${ }^{(1)}$, \\ Henrique Debiasi ${ }^{(1)}$ and Anderson Hideo Yokoyama ${ }^{(2)}$ \\ (1)Embrapa Soja, Rodovia Carlos João Strass, Distrito de Warta, Caixa Postal 231, CEP 86001-970 Londrina, PR, Brazil. E-mail: \\ alvadi.balbinot@embrapa.br, julio.franchini@embrapa.br, henrique.debiasi@embrapa.br (2)Universidade Estadual de Londrina, \\ Departamento de Agronomia, Rodovia Celso Garcia Cid, PR-445, Km 380, Caixa Postal 10.011, CEP 86057-970 Londrina, PR, Brazil. \\ E-mail: ahy19@hotmail.com
}

\begin{abstract}
The objective of this work was to evaluate the effect of roots and straw of palisade grass (Urochloa brizantha) and Ruzi grass (U. ruziziensis), used as cover crops in autumn-winter, on soybean performance. Seven treatments were evaluated in a randomized complete block design, with four replicates: fallow, during autumn-winter; straw of $U$. ruziziensis or $U$. brizantha 'BRS Piatã', distributed in plots kept under fallow in the winter, without roots; plots only with roots of U. ruziziensis or U. brizantha, without straw; and plots with straw and roots of $U$. ruziziensis or $U$. brizantha. The grass species were planted during the 2014/2015 crop season, and treatments were evaluated at the end of the 2015/2016 crop season, without drought during the soybean cycle. The oil and protein contents of soybean grains were not affected significantly by the treatments. However, the cultivation of grass species during autumn-winter increased soybean grain yield in comparison with fallow. Grass root effects are more expressive than those of straw. The combined presence of roots and straw confers a better performance to soybean than the isolated presence of roots or straw.
\end{abstract}

Index terms: Glycine max, Urochloa brizantha, Urochloa ruziziensis, cover crops, no-tillage.

\section{Contribuição de raízes e parte aérea de espécies de braquiárias no desempenho da soja em sucessão}

Resumo - O objetivo deste trabalho foi avaliar o efeito de raízes e palha de capim-piatã (Urochloa brizantha) e braquiária ruziziensis (U. ruziziensis), utilizados como plantas de cobertura do solo no outono-inverno, sobre o desempenho da cultura da soja. Foram avaliados sete tratamentos, em delineamento de blocos ao acaso, com quatro repetições: pousio, no outono-inverno; palha de U. ruziziensis ou de U. brizantha 'BRS Piatã', distribuída em parcelas mantidas em pousio no inverno, sem o uso de raízes; parcelas apenas com raízes de $U$. ruziziensis ou $U$. brizantha, sem o uso da palha; e parcelas com palha e raízes de U. ruziziensis ou $U$. brizantha. As braquiárias foram plantadas na safra 2014/2015, e os tratamentos foram avaliados ao final da safra 2015/2016, sem deficit hídrico durante o ciclo da soja. Os conteúdos de óleo e proteína nos grãos de soja não foram afetados significativamente pelos tratamentos. Entretanto, o cultivo das braquiárias durante o outono-inverno aumentou a produtividade de grãos da soja em sucessão, em comparação ao pousio. O impacto das raízes das braquiárias sobre a produtividade é mais expressivo do que o da palha. A presença combinada de raízes e palha confere melhor desempenho à soja do que a presença isolada de raízes ou palha.

Termos para indexação: Glycine max, Urochloa brizantha, Urochloa ruziziensis, cultivos de cobertura, plantio direto.

\section{Introduction}

In several regions of Brazil, there is a lack of alternatives for using the land between two soybean (Glycine $\max$ L.) crop seasons, mainly in areas with little water availability during the autumn-winter period. Therefore, it is common to keep these areas under fallow from March to September, which reduces the sustainability of the no-tillage system (NTS). An option for this period is to grow Urochloa (syn.
Brachiaria) species for their use either as cover crops or for fodder production in crop-livestock integration (CLI) (Balbinot Junior et al., 2009; Crusciol et al., 2015). The species $U$. ruzizizensis and U. brizantha show great capacity for dry matter production, even in low-fertility environments, and provide adequate soil cover (Timossi et al., 2007; Franchini et al., 2014a), high-nutrient cycling (Pacheco et al., 2011; Merlin et al., 2013), high-weed suppression capacity (Pacheco et 
al., 2008; Lima et al., 2014), and a reasonable ease of desiccation for planting crops in succession (Machado \& Assis, 2010).

In addition to the great potential for fodder production, grasses of this genus form biomass with high carbon/nitrogen ratio $(\mathrm{C} / \mathrm{N})$ and high content of lignin/N (Timossi et al., 2007), which confers to them a greater straw persistence - desirable mainly in hot environments, where there is a rapid decomposition of dry matter (Calonego et al., 2012).

The beneficial effects of Urochloa species on the productivity of soybean sown in succession may be attributed to their roots or straw. Urochloa roots improve the soil physical quality (Andrade et al., 2009; Crusciol et al., 2015), which may result in the increased infiltration and water retention, as well as in the improvement of the oxygen flow in the soil, and in the reduced soil resistance to root penetration. In addition, the root growth of $U$. ruziziensis increases the $\mathrm{P}$ availability to plants (Merlin et al., 2013), and straw reduces the rate of water evaporation from the soil, decreasing the peaks of heating (Dalmago et al., 2010) and weed infestation (Balbinot Jr. et al., 2007), reducing soil erosion (Schick et al., 2000), and releasing nutrients to crops in succession (Calonego et al., 2012). However, no studies were found in the literature reporting the separate effects of straw and roots of Urochloa spp. on the performance of soybean in succession.

Franchini et al. (2015) found that different amounts of $U$. ruziziensis straw, obtained with different pressures of grazing, did not affect the performance of soybean. These results seem to indicate that the contribution of roots to the soybean performance is higher than that of straw. In addition, high yields of soybean are common in areas of Urochloa pasture with little straw, or in which straw was removed for the production of hay or silage. In these cases, it is possible that the performance of soybean benefits from the improvement on the quality of soil structure resulting from the growth of grass roots. Thus, it is likely that, under NTS, Urochloa roots have a similar or higher impact on the growth and yield of soybean in succession, than that of straw.

The objective of this work was to evaluate the effect of roots and straw of palisade grass and Ruzi grass, used as cover crops in the autumn-winter period, on soybean performance.

\section{Materials and Methods}

The study was carried out in Londrina, PR $\left(23^{\circ} 12^{\prime} \mathrm{S}\right.$, $51^{\circ} 11^{\prime} \mathrm{W}$, at $585 \mathrm{~m}$ altitude). The soil of the experimental area was identified as a Latossolo Vermelho distrófico (Rhodic Hapludox) with the following attributes at 0.0-0.20 m soil depth, prior to the experiment setup: $750 \mathrm{~g} \mathrm{~kg}^{-1}$ clay; $21.4 \mathrm{~g} \mathrm{dm}^{-3}$ organic $\mathrm{C} ; 4.9 \mathrm{pH}$ in $\mathrm{CaCl}_{2}$; $8.6 \mathrm{mg} \mathrm{dm}^{-3} \mathrm{P} ; 0.55 \mathrm{cmol}_{\mathrm{c}} \mathrm{dm}^{-3} \mathrm{~K} ; 3.7 \mathrm{cmol}_{\mathrm{c}} \mathrm{dm}^{-3} \mathrm{Ca}$; $1.4 \mathrm{cmol}_{\mathrm{c}} \mathrm{dm}^{-3} \mathrm{Mg}$; and $52 \%$ base saturation. The soil had been managed under NTS for 15 years, with soybean growing in the summer, and wheat or black oat in the winter. The climate of the region is subtropical humid, Cfa according to Köppen-Geiger's classification, with $21^{\circ} \mathrm{C}$ average annual temperature, and $1,651 \mathrm{~mm}$ average annual rainfall.

Seven treatments were evaluated in a randomized block design, with four replicates: fallow, during the autumn-winter season (treatment 1); straw of Urochloa ruziziensis or U. brizantha 'BRS Piatã', distributed in plots kept under fallow in the winter, without roots (2 and 3); plots with roots either of $U$. ruziziensis or $U$. brizantha, without straw (4 and 5); and plots with straw and roots of $U$. ruziziensis or $U$. brizantha $(6$ and 7). The plots measured $8.0 \mathrm{~m}$ in length and $5.0 \mathrm{~m}$ in width. The area used in the evaluations was $9.0 \mathrm{~m}^{2}$ ( $6 \mathrm{~m}$ long by $1.5 \mathrm{~m}$ wide).

The Urochloa species were sown in November 2014, in consortium with soybean, using $7 \mathrm{~kg} \mathrm{ha}^{-1}$ of pure and viable seed, which were placed in lines allocated between the soybean rows, according to Franchini et al. (2014b). After the soybean harvest, in February 2015, the grasses remained as cover crops in the plots, in the autumn-winter period. In the fallow plots, there was a reduced weed infestation - sourgrass (Digitaria insularis), and hairy fleabane (Conyza spp.) -, which was controlled in August 2015. On 9/15/2015, the entire experimental area was desiccated with 2,160 $\mathrm{g} \mathrm{ha}^{-1}$ glyphosate acid equivalent, plus mineral oil. Early in October 2015, straw was manually removed from plots which should contain only roots of Urochloa (treatments 4 and 5), and it was allocated on plots where only straw would be used (treatments 2 and 3), without the presence of roots in the autumnwinter period.

On 11/11/2015, the soybean cultivar BRS 359 RR, which has an indeterminate growth and group of maturity on 6.0, was sown. The seeder (Semeato, model SHM 11/13) average speed was $5 \mathrm{~km} \mathrm{~h}^{-1}$, and

Pesq. agropec. bras., Brasília, v.52, n.8, p.592-598, ago. 2017 DOI: $10.1590 / \mathrm{S} 0100-204 X 2017000800004$ 
it was equipped with furrow openers of guillotinetype knife for fertilizers, shifted double disc for seed, and sieve-disc type dispensers with double-row holes for seed. Soybean seed were treated with VitavaxThiran 200SC (150 mL per bag of seed, $50 \mathrm{~kg}$ ), CoMo Platinum (100 mL per bag) and liquid inoculant Gelfix 5 (100 mL per bag). Basic fertilization consisted of $300 \mathrm{~kg} \mathrm{ha}^{-1}$ fertilizer application (formulation 0.20 .20 ) to the seeding furrow. The control of pest, disease, and weed was performed according to the technical indications for the culture. The sequential hydric balance for the summer season 2015/2016 in the experimental area is shown in Figure 1.

At the time of soybean sowing, the amount of straw produced by both grass species was evaluated in $1 \mathrm{~m}^{2}$ per plot, which was dried in an oven at $65^{\circ} \mathrm{C}$, weighed and relocated in the plots. The determinations obtained for soybean was performed as follows: stand in the stage V2 (Fehr \& Caviness, 1977), in $3 \mathrm{~m}^{2}$ per plot; shoot dry matter, in the V6 and $\mathrm{R} 3$, in $1 \mathrm{~m}^{2}$ per plot; and $\mathrm{N}$ concentration in the shoot dry matter, in V6 and R3, by the Kjeldahl method (Claessen, 1997). Nitrogen accumulation in dry matter was taken by multiplying the dry matter by the $\mathrm{N}$ content in the shoot; and the SPAD index, in R3, R4, R5.2, and R5.5, was determined in the central leaflet of the third open trefoil, from the apex to the base of the plant, in ten plants per plot. For the SPAD index evaluation, a chlorophyll meter Konica Minolta SPAD 502 was used, which applies parts of the red and infrared light spectra to estimate the chlorophyll content. The leaf area index in R3, R4, R5.2, and R5.5 was also determined, by using a plant canopy analyzer Li-cor LAI-2200; the grain yield and the levels of oil and protein in samples of wholesome grain were measured using the reflectance of near infrared (NIR), according to Heil (2010). For determinations with NIR, wholesome and clean grains from each sample were subjected to readings in the Thermo brand equipment model Antaris II, equipped with an integrating sphere of $4 \mathrm{~cm}^{-1}$ resolution, 32 scans, and background for each reading. The productivity of oil and protein was obtained by multiplying the grain yield by oil and protein contents.

Data were subjected to the normality and homoscedasticity analyses, and the Shapiro-Wilk and Hartley tests were used, respectively, which indicated

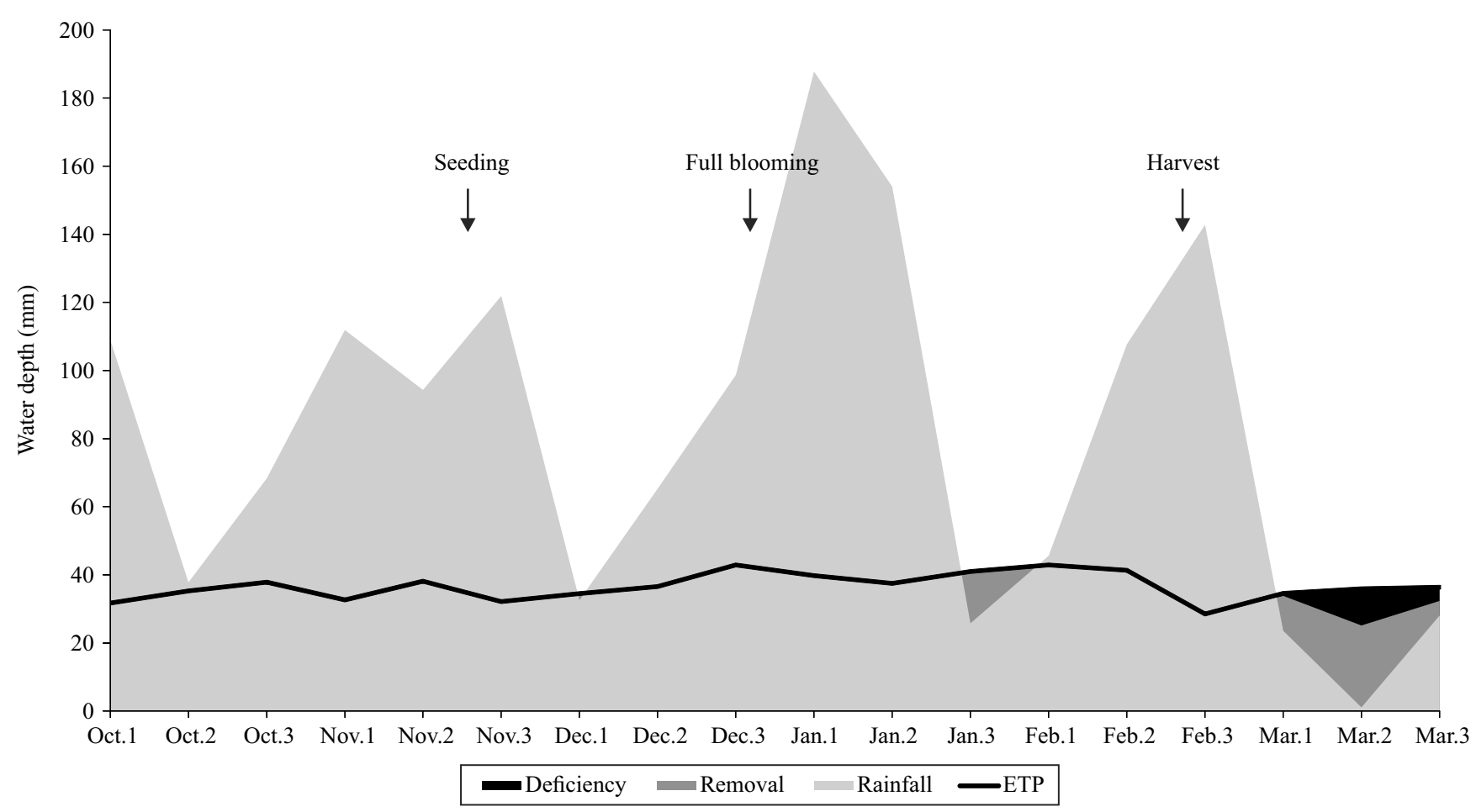

Figure 1. Sequential water balance (Thornthwaite \& Mather, 1955) observed between October 2015 and March 2016 at the experimental area. ETP, potential evapotranspiration. Londrina, PR, Brazil, 2015/2016 crop season. 
no need for the transformation of the data. Then, the data were subjected to the analysis of variance and the means were compared by the Scott-Knott's test, at $5 \%$ probability. Furthermore, the analysis of Pearson's linear correlation was also performed between the variables.

\section{Results and Discussion}

The production of straw by $U$. ruziziensis and U. brizantha 'BRS Piatã' was 7.4 and $14.8 \mathrm{Mg} \mathrm{ha}^{-1}$, respectively, which made evident the higher-yield potential of $U$. brizantha. Although treatments have produced a high amount of straw and roots, the soybean stand in succession was not affected by them (Table 1). Nepomuceno et al. (2012) also found that the soybean stand was not harmed by the presence of $10 \mathrm{Mg} \mathrm{ha}^{-1}$ straw of $U$. ruziziensis.

In the presence of $U$. brizantha roots, as well as in the treatment with roots and straw of the two evaluated Urochloa species, a greater dry matter mass was observed for soybean in succession, in the V6 (Table 1), which indicates that the imposed conditions by those treatments favored the soybean growth at the beginning of its development cycle. In the stage R3, in addition to those treatments, the evaluation of the treament of U. ruziziensis roots was also among those that provided a higher dry matter yield. These results confirm the positive impact that Urochloa cultivation in autumnwinter can have on the production environment, which is reflected in the higher dry matter yield of soybean. Alves et al. (2007) also reported the improvement of various soil physical properties - especially as to the rate of water infiltration - in a similar condition to that used in the present study, but using $U$. decumbens.
Silva et al. (2007) reported significant benefits to soil biological properties from the cultivation of $U$. brizantha 'Marandu'. Merlin et al. (2013) reported that the root growth of $U$. ruziziensis increases the $\mathrm{P}$ availability in the soil solution. Calonego et al. (2012) have quantified the significant release of nutrients after the mineralization of Urochloa straw.

The fallow treatment resulted in lower- $\mathrm{N}$ content in shoots, in the R3 stage (Table 1). This result is interesting, as it shows that the presence of straw and roots did not harm, but favored plant nutrition with this nutrient. In these conditions, it is worth noting that cover crops were desiccated 57 days before soybean sowing, which avoided the temporary $\mathrm{N}$ immobilization by the decomposition of straw and roots during the soybean growth. In addition, in the soil under fallow during autumn-winter period, soybean nodulation might have been hindered by the lack of straw and roots, since the biological $\mathrm{N}$ fixation by soybean is favored by adequate soil quality (Sindelar et al., 2016), usually associated with the large input of organic matter to the soil.

The fallow treatment, together with the strawonly treatments, resulted in lower-N accumulation in soybean shoots (Table 1). The accumulation of $\mathrm{N}$ in soybean shoots in R3 was positively correlated with grain yield $(\mathrm{r}=0.75)$. High-grain yields of soybean greater than $5 \mathrm{Mg} \mathrm{ha}^{-1}$ - is subjected to high rates of accumulation of dry matter and $\mathrm{N}$ by the crop (Van Roekel \& Purcell, 2014).

Fallow and straw-only treatments also showed the lowest values of Spad index at R3 stage (Table 2). With the advancement of the development cycle up to the R5.2 stage, no differences were observed in the SPAD index between treatments. At the R5.5, however, next to physiological maturity, SPAD index was lower only

Table 1. Establishment and growth of soybean (Glycine max) affected by the presence of straw and roots of Urochloa ruziziensis and U. brizantha 'BRS Piatã'(1).

\begin{tabular}{|c|c|c|c|c|c|}
\hline Treatment & $\begin{array}{c}\text { Stand V2 } \\
\left(1,000 \text { plants ha }^{-1}\right) \\
\end{array}$ & $\begin{array}{l}\text { Dry matter mass at V6 } \\
\left(\mathrm{kg} \mathrm{ha}^{-1}\right)\end{array}$ & $\begin{array}{c}\text { Dry matter mass at R3 } \\
\left(\mathrm{kg} \mathrm{ha}^{-1}\right)\end{array}$ & $\begin{array}{c}\text { N concentration at R3 } \\
(\%)\end{array}$ & $\begin{array}{l}\mathrm{N} \text { accumulation at R3 } \\
\left(\mathrm{kg} \mathrm{ha}^{-1}\right)\end{array}$ \\
\hline Fallow & $323^{\mathrm{ns}}$ & $848 \mathrm{~b}$ & $3,848 \mathrm{~b}$ & $2.16 \mathrm{~b}$ & $83 b$ \\
\hline Straw U. ruziziensis & 322 & $790 \mathrm{~b}$ & $4,094 b$ & $2.97 \mathrm{a}$ & $122 b$ \\
\hline Straw U. brizantha & 317 & $864 \mathrm{~b}$ & $4,118 b$ & $2.66 \mathrm{a}$ & $113 b$ \\
\hline Roots $U$.ruziziensis & 325 & $938 b$ & $4,786 a$ & $2.79 \mathrm{a}$ & $134 \mathrm{a}$ \\
\hline Roots $U$. brizantha & 312 & $1,134 \mathrm{a}$ & $5,480 \mathrm{a}$ & $2.99 a$ & $164 \mathrm{a}$ \\
\hline Straw and roots $U$. ruziziensis & 325 & $1,222 \mathrm{a}$ & $5,026 \mathrm{a}$ & $2.67 \mathrm{a}$ & $133 a$ \\
\hline Straw and roots $U$. brizantha & 303 & $1,066 \mathrm{a}$ & $4,916 \mathrm{a}$ & $3.01 \mathrm{a}$ & $150 \mathrm{a}$ \\
\hline Coefficient of variation (\%) & 8.3 & 17.3 & 16.8 & 10.4 & 16.4 \\
\hline
\end{tabular}

${ }^{(1)}$ Means followed by equal letters do not differ, by the Scott-Knott's test, at $5 \%$ probability. 
in the treatments with straw of $U$.ruziziensis and on fallow, which evidences that senescence may have been delayed in the other treatments. The highest correlation between the Spad index and grain yield was observed at the R5.2 ( $\mathrm{r}=0.71)$.

In the R3 stage, the lowest leaf area index (LAI) values of soybean were checked when the crop was sown after fallow, or after the straw-only treatment of $U$. ruziziensis or $U$. brizantha (Table 3 ). At the stages R4, R5.2, and R5.5, however, lower LAIs were consistently observed only in treatments with fallow and with $U$. ruziziensis straw. These results suggest the importance of Urochloa roots to the growth of soybean cultivated in succession. Similarly to what was observed with the SPAD index, the highest correlation between LAI and grain yield was observed at the R5.2 $(\mathrm{r}=0.88)$. Therefore, yield estimates through

Table 2. SPAD index at different phenological stages of soybean (Glycine max) crop according to the presence of straw and roots of Urochloa ruziziensis and U. brizantha 'BRS Piatã ${ }^{\prime(1)}$.

\begin{tabular}{lcccc}
\hline Treatment & $\mathrm{R} 3$ & $\mathrm{R} 4$ & $\mathrm{R} 5.2$ & $\mathrm{R} 5.5$ \\
\hline Fallow & $27.6 \mathrm{~b}$ & $25.6^{\mathrm{ns}}$ & $29.3^{\mathrm{ns}}$ & $34.4 \mathrm{~b}$ \\
Straw U. ruziziensis & $26.7 \mathrm{~b}$ & 27.5 & 33.0 & $34.2 \mathrm{~b}$ \\
Straw U. brizantha & $28.7 \mathrm{~b}$ & 28.3 & 32.5 & $38.0 \mathrm{a}$ \\
Roots U. ruziziensis & $31.0 \mathrm{a}$ & 29.6 & 34.6 & $36.1 \mathrm{~b}$ \\
Roots U. brizantha & $30.6 \mathrm{a}$ & 29.6 & 34.5 & $36.2 \mathrm{~b}$ \\
Straw and roots U. ruziziensis & $31.8 \mathrm{a}$ & 29.4 & 34.5 & $38.3 \mathrm{a}$ \\
Straw and roots U. brizantha & $30.6 \mathrm{a}$ & 30.5 & 33.7 & $38.5 \mathrm{a}$ \\
\hline Coefficient of variation (\%) & 6.8 & 9.5 & 9.4 & 5.6 \\
\hline
\end{tabular}

${ }^{(1)}$ Means followed by equal letters do not differ, by the Scott-Knott's test, at $5 \%$ probability. these variables should be carried out at the beginning of grain filling.

The lowest-grain yield occurred in the fallow treatment, as well as in the straw-only treatments, without the presence of roots (Table 4). The other treatments did not differ significantly, and indicated a greater relevance of Urochloa roots for the soybean yield, than that of straw. In the average of the two grass species, the increase of soybean grain yield granted by the addition of grass straw, in comparison with the treatment in fallow, was $22 \%\left(464 \mathrm{~kg} \mathrm{ha}^{-1}\right)$, whereas the soybean yield increase given by roots of the grasses species was $55 \%\left(1,155 \mathrm{~kg} \mathrm{ha}^{-1}\right)$. Therefore, the impact of roots of Urochloa species, used as cover crops in autumn-winter, was actually higher than that of their straw on soybean yield cultivated in succession, under NTS. This is in agreement with the hypothesis of this research. In this context, the withdrawal of

Table 3. Leaf area index (LAI) at different phenological stages of soybean (Glycine max) crop, in accordance with the presence of straw and roots of Urochloa ruziziensis and U. brizantha 'BRS Piatã ${ }^{\prime(1)}$.

\begin{tabular}{lcccc}
\hline Treatment & $\mathrm{R} 3$ & $\mathrm{R} 4$ & $\mathrm{R} 5.2$ & $\mathrm{R} 5.5$ \\
\hline Fallow & $3.48 \mathrm{~b}$ & $5.06 \mathrm{~b}$ & $3.59 \mathrm{~b}$ & $2.94 \mathrm{~b}$ \\
Straw U. ruziziensis & $3.04 \mathrm{~b}$ & $5.01 \mathrm{~b}$ & $3.48 \mathrm{~b}$ & $3.13 \mathrm{~b}$ \\
Straw U. brizantha & $4.15 \mathrm{~b}$ & $6.21 \mathrm{a}$ & $4.63 \mathrm{a}$ & $4.30 \mathrm{a}$ \\
Roots U. ruziziensis & $5.63 \mathrm{a}$ & $6.95 \mathrm{a}$ & $4.93 \mathrm{a}$ & $3.62 \mathrm{a}$ \\
Roots U. brizantha & $5.57 \mathrm{a}$ & $6.99 \mathrm{a}$ & $5.46 \mathrm{a}$ & $4.38 \mathrm{a}$ \\
Straw and roots $U$. ruziziensis & $5.88 \mathrm{a}$ & $7.21 \mathrm{a}$ & $4.98 \mathrm{a}$ & $3.88 \mathrm{a}$ \\
Straw and roots U. brizantha & $5.22 \mathrm{a}$ & $7.47 \mathrm{a}$ & $5.18 \mathrm{a}$ & $4.36 \mathrm{a}$ \\
\hline Coefficient of variation $(\%)$ & 15.7 & 10.9 & 12.0 & 15.2 \\
\hline
\end{tabular}

${ }^{(1)}$ Means followed by equal letters do not differ, by the Scott-Knott's test, at $5 \%$ probability.

Table 4. Grain yield, oil and protein content of soybean (Glycine max) affected by the presence of straw and roots of Urochloa ruziziensis and $U$. brizantha 'BRS Piatã'(1).

\begin{tabular}{|c|c|c|c|c|c|}
\hline Treatment & $\begin{array}{c}\text { Yield } \\
\left(\mathrm{kg} \mathrm{ha}^{-1}\right)\end{array}$ & $\begin{array}{c}\text { Oil content } \\
(\%)\end{array}$ & $\begin{array}{c}\text { Protein content } \\
(\%)\end{array}$ & $\begin{array}{l}\text { Oil productivity } \\
\left(\mathrm{kg} \mathrm{ha}^{-1}\right)\end{array}$ & $\begin{array}{l}\text { Protein productivity } \\
\qquad\left(\mathrm{kg} \mathrm{ha}^{-1}\right)\end{array}$ \\
\hline Fallow & $2,087 \mathrm{~b}$ & $25.6^{\mathrm{ns}}$ & $34.3^{\mathrm{ns}}$ & $536 b$ & $712 \mathrm{c}$ \\
\hline Straw U. ruziziensis & $2,364 b$ & 25.1 & 35.2 & $594 b$ & $833 c$ \\
\hline Straw U. brizantha & $2,739 b$ & 23.7 & 36.2 & $642 b$ & $999 \mathrm{c}$ \\
\hline Roots U. ruziziensis & $3,134 \mathrm{a}$ & 24.3 & 35.2 & $764 a$ & $1,103 b$ \\
\hline Roots $U$. brizantha & $3,350 \mathrm{a}$ & 24.4 & 35.1 & $818 \mathrm{a}$ & $1,178 b$ \\
\hline Straw and roots $U$. ruziziensis & $3,823 \mathrm{a}$ & 23.8 & 36.7 & $910 \mathrm{a}$ & $1,405 \mathrm{a}$ \\
\hline Straw and roots $U$. brizantha & $3,720 \mathrm{a}$ & 24.0 & 36.9 & $887 \mathrm{a}$ & $1,380 \mathrm{a}$ \\
\hline Coefficient of variation (\%) & 13.0 & 4.4 & 3.8 & 12.0 & 14.8 \\
\hline
\end{tabular}

${ }^{(1)}$ Means followed by equal letters do not differ, by the Scott-Knott's test, at $5 \%$ probability. 
the Urochloa shoot, planted during the soybean offseason for the production of hay or silage, or even for grazing, would not eliminate the benefits of this crop on soybean in succession. However, it must be emphasized that there was no occurrence of water deficit during the cultivation of soybean (Figure 1). It is likely that, if it had occurred, the importance of the presence of straw in the treatments would be increased, due to its potential to reduce water losses by evaporation (Borges et al., 2014). Another aspect that needs further investigation is related to the cumulative effects of straw or roots on the soil properties, and on the productive performance of soybean in long-term experiments.

In the treatments with straw and roots, the increase of soybean grain yield, in comparison with fallow, was $81 \%\left(1,684 \mathrm{~kg} \mathrm{ha}^{-1}\right)$. The sum of the isolated effects of straw $\left(464 \mathrm{~kg} \mathrm{ha}^{-1}\right)$ and roots $\left(1,155 \mathrm{~kg} \mathrm{ha}^{-1}\right)$ on soybean yield was similar $\left(1,619 \mathrm{~kg} \mathrm{ha}^{-1}\right)$ to that observed in the presence of the two components, which indicates the occurrence of additive effects. Another interesting result is that the impact of the two grass species on soybean was similar, despite the greater $U$. brizantha production of straw and, probably, of roots.

The oil and protein contents of soybean grains were not affected significantly by the treatments (Table 4). This indicates that, in the absence of water deficit, these variables are less affected by the soil management prior to soybean cultivation. However, the productivity of oil and protein per area was strongly influenced by the treatments, mainly as a result of the great impact of these on grain yield. The fallow and straw-only treatments granted the lowest yield of oil. As for protein, it was found that the treatments with straw and roots have provided the highest soybean yield, whereas the fallow and the straw-only treatments provided the lowest one.

\section{Conclusions}

1. The cultivation of Urochloa ruzizizensis and $U$. brizantha 'BRS Piatã' as cover crops, in the period of autumn-winter, increases the grain yield of soybean (Glycine max) in succession, in comparison with fallow.

2. The impact of the Urochloa species roots on soybean yield is more expressive than that of straw (shoots), when there is no water deficit during the cultivation of the oleaginous crop.
3. The simultaneous use of roots and straw of Urochloa species gives better agronomic performance to soybean than the isolated presence of roots or straw.

\section{Acknowledgments}

To Conselho Nacional de Desenvolvimento Científico e Tecnológico ( $\mathrm{CNPq}$ ), for granting the first author with a fellowship of productivity for technological development and innovative extension.

\section{References}

ALVES, M.C.; SUZUKI, L.G.A.S.; SUZUKI, L.E.A.S. Densidade do solo e infiltração de água como indicadores da qualidade física de um Latossolo Vermelho distrófico em recuperação. Revista Brasileira de Ciência do Solo, v.31, p.617-625, 2007. DOI: 10.1590/S0100-06832007000400002.

ANDRADE, R. da S.; STONE, L.F.; SILVEIRA, P.M. da. Culturas de cobertura e qualidade física de um Latossolo em plantio direto. Revista Brasileira de Engenharia Agrícola e Ambiental, v.13, p.411-418, 2009. DOI: 10.1590/S1415-43662009000400007.

BALBINOT JR., A.A.; MORAES, A.; BACKES, R.L. Efeito de coberturas de inverno e sua época de manejo sobre a infestação de plantas daninhas na cultura de milho. Planta Daninha, v.25, p.473-480, 2007. DOI: 10.1590/S0100-83582007000300006.

BALBINOT JUNIOR, A.A.; MORAES, A. de; VEIGA, M. da; PELISSARI, A.; DIECKOW, J. Integração lavoura-pecuária: intensificação de uso de áreas agrícolas. Ciência Rural, v.39, p.1925-1933, 2009. DOI: 10.1590/S0103-84782009005000107.

BORGES, T.K. de S.; MONTENEGRO, A.A. de A.; SANTOS, T.E.M. dos; SILVA, D.D. da; SILVA JUNIOR, V. de P. e. Influência de práticas conservacionistas na umidade do solo e no cultivo do milho (Zea mays L.) em semiárido nordestino. Revista Brasileira de Ciência do Solo, v.38, p.1862-1873, 2014. DOI: 10.1590/S010006832014000600021.

CALONEGO, J.C.; GIL, F.C.; ROCCO, V.F.; SANTOS, E.A. dos. Persistência e liberação de nutrientes da palha de milho, braquiária e labe-labe. Bioscience Journal, v.28, p.770-781, 2012.

CLAESSEN, M.E.C. (Org.). Manual de métodos e análise de solo. 2.ed. rev. e atual. Rio de Janeiro: Embrapa-CNPS, 1997. 212p. (EMBRAPA-CNPS. Documentos, 1).

CRUSCIOL, C.A.C.; NASCENTE, A.S.; BORGHI, E.; SORATTO, R.P.; MARTINS, P.O. Improving soil fertility and crop yield in a tropical region with palisadegrass cover crops. Agronomy Journal, v.107, p.2271-2280, 2015. DOI: 10.2134/ agronj14.0603.

DALMAGO, G.A.; BERGAMASCHI, H.; KRÜGER, C.A.M.B.; BERGONCI, J.I.; COMIRAN, F.; HECKLER, B.M.M. Evaporação da água na superfície do solo em sistemas de plantio direto e preparo convencional. Pesquisa Agropecuária Brasileira, v.45, p.780-790, 2010. DOI: 10.1590/S0100-204X2010000800002. 
FEHR, W.R.; CAVINESS, C.E. Stages of soybean development. Ames: Iowa State University of Science and Technology, 1977. 11p. (Iowa State University of Science and Technology. Agriculture and Home Economics Experiment Station. Cooperative Extension Service. Special report, 80).

FRANCHINI, J.C.; BALBINOT JUNIOR, A.A.; DEBIASI, H.; CONTE, O. Desempenho da soja em consequência de manejo de pastagem, época de dessecação e adubação nitrogenada. Pesquisa Agropecuária Brasileira, v.50, p.1131-1138, 2015. DOI: 10.1590/ S0100-204X2015001200002.

FRANCHINI, J.C.; BALBINOT JUNIOR, A.A.; DEBIASI, H.; CONTE, O. Soybean performance as affected by desiccation time of Urochloa ruziziensis and grazing pressures. Revista Ciência Agronômica, v.45, p.999-1005, 2014a. Especial. DOI: 10.1590/ S1806-66902014000500015.

FRANCHINI, J.C.; BALBINOT JUNIOR, A.A.; DEBIASI, H.; PROCÓPIO, S. de O. Intercropping of soybean cultivars with Urochloa. Pesquisa Agropecuária Tropical, v.44, p.119-126, 2014b. DOI: 10.1590/S1983-40632014000200007.

HEIL, C. Rapid, multi-component analysis of soybeans by FT-NIR spectroscopy. Madison: Thermo Fisher Scientific, 2010 3p. (Application note: 51954). Available at: $<$ https://www. thermoscientific.com/content/dam/tfs/ATG/CMD/CMD $\% 20$ Documents/Application\%20\&\%20Technical\%20Notes/AN51954-Rapid-Multi-Component-Analysis-Soybeans-AN51954EN.pdf>. Accessed on: Nov. 152015.

LIMA, S.F.; TIMOSSI, P.C.; ALMEIDA, D.P.; SILVA, U.R. da. Palhada de braquiária ruziziensis na supressão de plantas daninhas na cultura da soja. Revista Agrarian, v.7, p.541-551, 2014.

MACHADO, L.A.Z.; ASSIS, P.G.G. de. Produção de palha e forragem por espécies anuais e perenes em sucessão à soja. Pesquisa Agropecuária Brasileira, v.45, p.415-422, 2010. DOI: 10.1590/s0100-204x2010000400010.

MERLIN, A.; HE, Z.L.; ROSOLEM, C.A. Ruzigrass affecting soilphosphorus availability. Pesquisa Agropecuária Brasileira, v.48, p.1583-1588, 2013. DOI: 10.1590/S0100-204X2013001200007.

NEPOMUCENO, M.P.; VARELA, R.M.; ALVES, P.L.C.A.; MARTINS, J.V.F. Períodos de dessecação de Urochloa ruziziensis e seu reflexo na produtividade da soja RR. Planta Daninha, v.30, p.557-565, 2012. DOI: 10.1590/S0100-83582012000300011.

PACHECO, L.P.; LEANDRO, W.M.; MACHADO, P.L.O. de A.; ASSIS, R.L. de; COBUCCI, T.; MADARI, B.E.; PETTER, F.A. Produção de fitomassa e acúmulo e liberação de nutrientes por plantas de cobertura na safrinha. Pesquisa Agropecuária Brasileira, v.46, p.17-25, 2011. DOI: 10.1590/S0100204X2011000100003.

PACHECO, L.P.; PIRES, F.R.; MONTEIRO, F.P.; PROCÓPIO, S. de O.; ASSIS, R.L. de; CARMO, M.L. do; PETTER, F.A. Desempenho de plantas de cobertura em sobressemadura na cultura da soja. Pesquisa Agropecuária Brasileira, v.43, p.815823, 2008. DOI: 10.1590/S0100-204X2008000700005.

SCHICK, J.; BERTOL, I.; BATISTELA, O.; BALBINOT JÚNIOR, A.A. Erosão hídrica em Cambissolo Húmico alumínico submetido a diferentes sistemas de preparo e cultivo do solo. I: perdas de solo e água. Revista Brasileira de Ciência do Solo, v.24, p.427-436, 2000.

SILVA, M.B. da; KLIEMANN, H.J.; SILVEIRA, P.M. da; LANNA, A.C. Atributos biológicos do solo sob influência da cobertura vegetal e do sistema de manejo. Pesquisa Agropecuária Brasileira, v.42, p.1755-1761, 2007. DOI: 10.1590/ S0100-204X2007001200013.

SINDELAR, A.J.; SCHMER, M.R.; JIN, V.L.; WIENHOLD, B.J.; VARVEL, G.E. Crop rotation affects corn, grain sorghum, and soybean yields and nitrogen recovery. Agronomy Journal, v.108, p.1592-162, 2016. DOI: 10.2134/agronj2016.01.0005.

THORNTHWAITE, C.W.; MATHER, J.R. The water balance. Centerton: Drexel Institute of Technology, Laboratory of Climatology, 1955. 104p. (Publications in Climatology, v. 8).

TIMOSSI, P.C.; DURIGAN, J.C.; LEITE, G.J. Formação de palhada por braquiárias para adoção do sistema plantio direto. Bragantia, v.66, p.617-622, 2007. DOI: 10.1590/S000687052007000400012 .

VAN ROEKEL, R.J.; PURCELL, L.C. Soybean biomass and nitrogen accumulation rates and radiation use efficiency in a maximum yield environment. Crop Science, v.54, p.1189-1196, 2014. DOI: $10.2135 /$ cropsci2013.08.0546.

$\overline{\text { Received on August 12, } 2016 \text { and accepted on December 29, } 2016}$ 